\title{
AGRONOMIC TECHNIQUES FOR MITIGATING THE EFFECTS OF WATER RESTRICTION ON COFFEE CROPS
}

\author{
Dalyse Toledo Castanheira ${ }^{1}$, Thales Resende Barcelos², Rubens José Guimarães ${ }^{3}$, \\ Milene Alves de Figueiredo Carvalho ${ }^{4}$, Tiago Teruel Rezende ${ }^{5}$, Isadora dos Santos Bastos ${ }^{6}$, \\ Arthur Henrique Cruvinel $^{7}$
}

(Received: January 23, 2019; accepted: February 18, 2019)

\begin{abstract}
Water restriction significantly affects coffee (Coffea arabica L.) production. The study of a few agronomic techniques that optimizes water use can generate technologies for mitigating the effects of climatic variations on coffee crops. The aim in this study was to indicate agronomic techniques that mitigate the effects of water restriction on coffee crops. For this end, we analyzed the morphophysiological changes in coffee plants cultivated in a greenhouse with different types of fertilizers and soil conditioners and under two levels of irrigation. The evaluations were performed 130 days after planting, assessing the morphological and physiological characteristics of the plants. We also quantified soil moisture in the different treatments. The water restriction expressively hindered plant growth. The use of controlled release fertilizers and soil conditioners, especially coffee husk, is indicated for mitigating water restriction in coffee crops.
\end{abstract}

Index Terms: Coffea arabica L., climatic variations, water use efficiency.

\section{TÉCNICAS AGRONÔMICAS PARA A MITIGAÇÃO DOS EFEITOS DA RESTRIÇÃO HÍDRICA NO CAFEEIRO}

\begin{abstract}
RESUMO: A restrição hídrica já afeta significativamente a produção do cafeeiro (Coffea arabica L.). O estudo de algumas técnicas agronômicas que proporcionem a otimização da água poderá gerar tecnologias eficazes na mitigação dos efeitos das variações climáticas na cultura do café. Objetivou-se neste trabalho indicar técnicas agronômicas que mitiguem os efeitos da restrição hídrica em cafeeiro. Para isso foram analisadas as alterações morfofisiológicas em cafeeiros cultivados em casa de vegetação com diferentes tipos de fertilizantes e condicionadores de solo sob dois níveis de irrigação. As avaliações foram realizadas aos 130 dias após o plantio. Foram avaliadas características morfológicas e fisiológicas das plantas. Também se quantificou a umidade do solo nos diferentes tratamentos. A restrição hídrica prejudicou de forma expressiva o crescimento do cafeeiro. Fertilizantes de liberação controlada e condicionadores de solo, em especial a casca de café, são técnicas agronômicas indicadas para mitigação da restrição hídrica em cafeeiros.
\end{abstract}

Termos para indexação: Coffea arabica L., Variações climáticas, Eficiência do uso da água.

\section{INTRODUCTION}

Water availability is one of the most limiting of the essential plants growth factors and contributes significantly to an increased agricultural production worldwide. Most coffee plant tissues are approximately $85 \%$ water, which is also the principle medium for chemical processes that support plants metabolism (TAIZ; ZEIGER, 2013).

Climate is continually varying on time scales ranging from days to seasons. However, considering temperature increase and reduction in water availability as consequences of climatic variations (IPCC, 2014), the study on agronomic techniques aiming to minimize such impacts is found to be an utmost important approach for agriculture. Regarding coffee plants, a significant loss of areas considered suitable for the cultivation of Coffea arabica L. and Coffea canephora Pierre is likely to happen (BUNN, 2015).

The increased efficiency fertilizers are emphasized as a great alternative for plant nutrition under adverse cropping conditions. These fertilizers show greater efficiency in providing nutrients to plants and allow the reduction of nutrients losses through leaching and volatilization, making fertilization safer (TIMILSENA et al., 2015).

Few soil conditioners such as agricultural gypsum and organic residues enhance soil properties and root environment, then allowing better access to available water for plants (SANTOS et al., 2014).

A successfully study on water-retaining polymer able to retain and provide water to plants

\footnotetext{
1,23,67 Universidade Federal de Lavras/UFLA - Departamento de AgriculturaDAG - Cx. P. 3037 - 37.200-000 - Lavras - MG - dalysecastanheira@hotmail.com, rubensjg@dag.ufla.br, thales_br@outlook.com, isadorabs9200@gmail.com, arthurhcruvinel@hotmail.com

${ }^{4}$ Embrapa Café - Parque Estação Biológica - Av. W3 Norte - Cx. P. 40315 - 70.770-90 - Brasília - DF - milene.carvalho@embrapa.br ${ }^{5}$ Universidade José do Rosário Vellano - Instituto de Ciências Agrarias - Escola de Agronomia - Rodovia MG-179 - 37.1132 - 440 Alfenas - MG - tiago.rezende@unifenas.br
} 
for extended periods of time was developed in coffee crops and shown as a potential tool for water optimization in crops production processes (SOUZA et al., 2016).

However, there is no information regarding the effects of the simultaneous use of technologies such as controlled release fertilizers and soil conditioners with higher water use efficiency in coffee crops. Thus, it highlights here the relevance of developing a sustainable coffee production process.

Anatomical and physiological aspects, as well as the aerial parts growth and root systems of plants, can help in choosing the technology that better mitigates the effects of water restriction (CASTANHEIRA et al., 2016). Therefore, this study was developed aiming to describe agronomic methods that better mitigate the effects of water restriction on coffee crops.

\section{MATERIALS AND METHODS}

\section{Study site, growth conditions and experiment design}

The experiment was carried out in a greenhouse, in the municipality of Lavras, State of Minas Gerais, Brazil, at latitude $21^{\circ} 15^{\prime}$ S, longitude $45^{\circ} 00^{\prime} \mathrm{W}$ and $918 \mathrm{~m}$ elevation. An electronic gauge was used to measure the temperature, relative humidity and luminance during the experiment development and mean estimates were $21.36^{\circ}$, $64 \%$ and 8945.14 lx, respectively.

Coffee seedlings (Coffea arabica L.) of cultivar Mundo Novo IAC 379/19 were planted, when containing four pairs of leaves, in 14-liters pots arranged on a stand at $0.8 \mathrm{~m}$ height. The substrate used to fill up pots was Humic Rhodic Acrudox, clayey texture with $67 \%$ clay, $15 \%$ silt and $18 \%$ sand and the following chemical characteristics: $\mathrm{pH} 5.8,22 \mathrm{mg} \mathrm{dm}^{-3} \mathrm{~K}, 0.28 \mathrm{mg}$ $\mathrm{dm}^{-3} \mathrm{P}, 0.3 \mathrm{cmol}_{\mathrm{c}} \mathrm{dm}^{-3} \mathrm{Ca}, 0.1 \mathrm{cmol}_{\mathrm{c}} \mathrm{dm}^{-3} \mathrm{Mg}, 0.0$ $\mathrm{cmol}_{\mathrm{c}} \mathrm{dm}^{-3} \mathrm{Al}, 0.84 \mathrm{cmol}_{\mathrm{c}} \mathrm{dm}^{-3}$ potential acidity $\left(\mathrm{H}+\mathrm{Al}\right.$ ), $0.46 \mathrm{cmol}_{\mathrm{c}} \mathrm{dm}^{-3} \mathrm{sum}$ of bases (SB), 0.46 cmol $\mathrm{dm}^{-3}$ effective cation exchange capacity $(\mathrm{t})$, $1.3 \mathrm{cmol}_{\mathrm{c}} \mathrm{dm}^{-3}$ cation exchange capacity at $\mathrm{pH} 7.0$ (T), $35.11 \%$ base saturation (V), $0.0 \%$ aluminum saturation (m), $0.04 \mathrm{dag} \mathrm{kg}^{-1}$ organic matter (OM), $1.52 \mathrm{mg} \mathrm{L}^{-1}$ reminiscent phosphorus (P-rem), 0.59 $\mathrm{mg} \mathrm{dm}^{-3} \mathrm{Zn}, 34.67 \mathrm{mg} \mathrm{dm}^{-3} \mathrm{Fe}, 4.30 \mathrm{mg} \mathrm{dm}^{-3} \mathrm{Mn}$, $0.57 \mathrm{mg} \mathrm{dm}^{-3} \mathrm{Cu}, 0.56 \mathrm{mg} \mathrm{dm}^{-3} \mathrm{~B}$ and $7.82 \mathrm{mg}$ $\mathrm{dm}^{-3} \mathrm{~S}$.

The correction of soil acidity was carried out by raising the base saturation to $70 \%$ using $570 \mathrm{~kg} \mathrm{ha}^{-1}$ of dolomitic limestone with $35 \%$
$\mathrm{CaO}$ and $14 \% \mathrm{MgO}$ and $80 \%$ effective calcium carbonate (ECC). The limestone was added to the soil substrate and incubated in pots for 60 days, keeping the moisture at $60 \%$ total pore volume (TPV) occupied by water. Phosphate fertilizer was applied during planting as outlined in Malavolta (1981), using Single Superphosphate $\left(21 \% \mathrm{P}_{2} \mathrm{O}_{5}\right)$.

After planting seedlings into pots, the substrate moisture was kept at $100 \%$ field capacity for 30 days to ensure the full establishment of seedlings and growth uniformity. Then, the irrigation was performed as per each treatment.

The experiment was carried out in randomized block design with four replicates. Treatments were arranged in $2 \times 2 \times 5$ factorial scheme, where two levels of irrigation ( $40 \%$ and $80 \%$ of field capacity), two types of fertilizers (conventional fertilizer and controlled release fertilizer) and five types of soil conditioners (coffee husk, agricultural gypsum, water-retaining polymer, organic compost and negative control or treatment without soil conditioners). A total of 80 plots were used, each plot consisting of one pot.

\section{Irrigation, fertilizers and conditioners management}

The irrigation water was replaced based on the gravimetric weight difference estimated by means of electronic scales. The weight of pots under field capacity conditions was measured. Then, the weight of pots for each treatment, at $40 \%$ and $80 \%$ field capacity was also measured (LANNA et al., 2016).

Seedlings were checked three times a week (Monday, Wednesday and Friday) to assess the need for irrigation, using two reference pots located at strategic points inside the greenhouse, one for each level of irrigation. The evapotranspiration of water from seedlings leaves led to weigh losses. Thus, seedlings were then irrigated to reestablish the corresponding weight for each treatment (LANNA et al., 2016).

Two types of fertilizers were used to supply nitrogen $(\mathrm{N})$ and potassium $(\mathrm{K})$ to coffee plants. The conventional fertilizer consisted of 20-00-20 (N-P-K) and urea, used in cover application on planting day and at 30 and 60 days after planting, as outlined in Guimarães et al. (1999). The controlled release fertilizer consisted of a commercial product containing $37 \% \mathrm{~N}$ and urea coated with elemental sulfur particles plus a layer of organic polymers and another commercial product containing 52\% $\mathrm{K}_{2} \mathrm{O}$ with potassium chloride, also coated with elemental sulfur particles plus a layer of organic 
polymers. A single application of fertilizers was done at planting date via side holes, according to manufacturer's instructions.

Doses of fertilizer were estimated as outlined in Malavolta (1981), considering a supplement of $300 \mathrm{ppm} \mathrm{N}$ and $150 \mathrm{ppm} \mathrm{K}$.

Coffee husk, organic compost and gypsum soil conditioners were applied as cover at planting date, as outlined in Guimarães et al. (1999). For treatments containing coffee husk and organic compost, $0.16 \mathrm{~L} \mathrm{dm}^{-3}$ was added. The organic compost consisted of a commercial product containing farm and food industry residues. An amount of $0.7 \mathrm{~g} \mathrm{dm}^{-3}$ estimated based on the type of soil texture was added to the treatment containing agricultural gypsum.

Regarding treatments containing waterretaining polymer, the solution was prepared adding $1.5 \mathrm{~kg}$ of polymer in 400 liters of water. Then 1.5 liters of the obtained solution was applied in the planting hole (SOUZA et al., 2016).

\section{Measurements}

Field data collect was performed for 130 days after planting due to the growth limitation of plants under water restriction. The following parameters were evaluated: plant height in $\mathrm{cm}$, measured using graduated scale; stem diameter in $\mathrm{mm}$, measured using digital pachymeter; number of leaves; number of plagiotropic branches; total root length in $\mathrm{cm}$, obtained as the sum of the linear extension of each fragment of the root system and measured using the Safira program; dry weight of the aerial part in g; and dry weight of the root system in g. To evaluate the dry weight, plants were harvested, separated into aerial part and roots, washed in running water and dried in a forced air heating system (hothouse) at $65^{\circ}$ until reaching a constant weight.

For anatomical studies, fully expanded leaves located between the second and third node from the tip of the orthotropic branch were collected and, then, placed on germitest paper previously identified according to treatments and moisturized with deionized water. Paradermic sections were obtained in the laboratory by the impression of the epidermis, using the leaf printing technique with universal instantaneous adhesive (cyanoacrylate ester). For obtaining transversal sections, leaves were fixed in $70 \%$ ethanol $\left(\mathrm{v} \mathrm{v}^{-1}\right)$ and, after 72 hours, exchanged for the same reagent for good biomass conservation.

The dehydration process of biomass in series of ethyl was also performed. The plant material was placed in methacrylate according to the manufacturer's instructions and divided into sections approximately $0.8 \mu \mathrm{m}$ thickness using a rotary microtome. Sections were stained using toluidine blue dye (O'BRIEN; FEDER; MCCULLY, 1964) and slides were assembled using Entelan ${ }^{\circledR}$ as medium. Slides were observed with an optic microscope and photographs captured with a digital camera coupled to it. Images were analyzed using the UTHSCSAImagetool program.

The number of stomata, the polar diameter of the stomata and the equatorial diameter of the stomata were evaluated for stomatal characterization. The stomatal density (number of stomata per $\mathrm{mm}^{2}$ ) and the ratio polar diameter/ equatorial diameter of the stomata, which is highly correlated to stomatal functioning were calculated (SOUZA et al., 2010, 2013). The adaxial epidermis thickness, palisade parenchyma thickness, spongy parenchyma thickness and mesophile thickness were evaluated to determine the thickness of leaf tissues. The thickness of the phloem region, the diameter of xylem vessels and the number of xylem vessels were measured for the evaluation of the vascular beams.

A portable gauge was used for gas analysis in the infrared region (LI 6400-XT, LICOR), seeking to evaluate the gas exchanges. The net photosynthetic rate $\left(\mu \mathrm{mol} \mathrm{CO} \mathrm{m}^{-2} \mathrm{~s}^{-1}\right)$, stomatal conductance $\left(\mathrm{mol} \mathrm{H} \mathrm{H}_{2} \mathrm{O} \mathrm{m}^{-2} \mathrm{~s}^{-1}\right)$ and the transpiration rate $\left(\mathrm{mmol} \mathrm{H} \mathrm{H}_{2} \mathrm{O} \mathrm{m}^{-2} \mathrm{~s}^{-1}\right)$ were evaluated. The instantaneous water use efficiency ( $\mu \mathrm{mol} \mathrm{CO} \mathrm{mmol}^{-1} \mathrm{H}_{2} \mathrm{O}$ ) was calculated using the photosynthetic rate/transpiration rate ratio (YAN et al., 2015). Evaluations were conducted from 8:00 a.m. to 11:00 a.m, under artificial lighting (1000 $\mu \mathrm{mol} \mathrm{m} \mathrm{m}^{-2} \mathrm{~s}^{-1}$ ), using fully expanded leaves located at the third node from the tip of the orthotropic branch.

The leaf water potential (MPa) was determined in the early morning using a Scholander pressure chamber (model 1000, PMS Instrument Company). Leaves fully expanded and without symptoms of pests and/ or diseases were collected for evaluation in a chamber applying pressure until it could observe exudation runoff from the cut section of the leaf petiole.

A simple and deformed sample was collected at $15 \mathrm{~cm}$ depth from each plot to assess the soil moisture. The wet weight was measured using a precision scale and samples were placed in a hothouse at $105^{\circ} \mathrm{C}$ until reaching constant weight. Then, the dry weight and percentage of water in the soil were estimated. 


\section{Statistical analysis}

The R statistical software (2016) was run for Analysis of Variance to verify the significance of variation sources using the $\mathrm{F}$ test at 5\% probability. The aov package was used to adjust the linear model and the summery function was used for Analysis of Variance. The Scott-Knott test was used to compare means at 5\% significance.

\section{RESULTS AND DISCUSSION}

Results on interactions within levels of irrigation, types of fertilizers and types of soil conditioners under study did not show differences at $5 \%$ probability $(p>0.05)$. However, there were differences for interactions between factors $(p<$ 0.05), as follows: (i) levels of irrigation and types of soil conditioner; (ii) types of fertilizer and types of soil conditioner; and (iii) levels of irrigation and types of fertilizer. In addition, differences were also found for each of factor effects under study $(p<0.05)$.

Higher plants growth was recorded for most of types of soil conditioners when compared to levels of irrigation at $80 \%$ of field capacity and adequate water availability for the crop (TABLE 1). However, the same trend was found with regard to plants grown in soil conditioners containing coffee husk and organic compost, both used at $40 \%$ irrigation level, for the following variables: plants height, stem diameter, number of leaves, number of plagiotropic branches, dry weight of the aerial part and dry weight of the root system, as well as for stem diameter and dry weight of the root system when used waterretaining conditioner also associated with $40 \%$ irrigation. Lesser estimates were found for plant height, number of leaves, number of plagiotropic branches and dry weight of the aerial part, with regard to plants grown under water-retaining polymer, agricultural gypsum and negative control (treatment without soil conditioners), under water restricting conditions (TABLE 1).

The coffee husk allowed better plant growth, with higher values of plant height, number of leaves, dry weight of the aerial part and dry weight of the root system for plants under waterrestricting at $40 \%$ field capacity. The organic compost showed lesser values when compared to coffee husk. However, such estimates were greater than those found for treatments consisting of the following plants growth factors: water-retaining polymer, agricultural gypsum and negative control. Regarding coffee husk and organic compost, both associated with water restriction, plants showed stem diameter and number of plagiotropic branches superior to those found for other conditioners (TABLE 1).

Regarding interaction between types of soil conditioners and levels of irrigation, there was no differences at $80 \%$ field capacity $(p>0.05)$ for the following variables: palisade parenchyma thickness, spongy parenchyma thickness, mesophile thickness, xylem vessel diameter, number of xylem vessels and leaf water potential (TABLE 1).

Estimate of palisade parenchyma thickness was greater in plants grown under water-retaining polymer and the negative control. Estimates of xylem vessel diameter and number of xylem vessels were greater in plants grown under coffee husk and organic compost and lesser for treatments consisting of the following plants growth factors: water-retaining polymer, agricultural gypsum and the negative control. Besides, lesser estimates were obtained for spongy parenchyma thickness, mesophile thickness and number of xylem vessels with regard to plants grown in agricultural gypsum (TABLE 1).

Plants grown in coffee husk showed greater estimates of leaf water potential, followed by plants grown in organic compost, both at $40 \%$ irrigation. However, plants grown in water-retaining polymer and agricultural gypsum, showed not differences (TABLE 1). Plants of the negative control showed lesser estimates of leaf water potential. However, plants grown in coffee husk and organic compost at $40 \%$ irrigation showed estimates of leaf water potential with a trend similar to those found for plants grown at $80 \%$ irrigation, for either plant height, stem diameter, number of leaves, number of plagiotropic branches, dry weight of the aerial part, dry weight of the root system, xylem vessel diameter of number of xylem vessels (TABLE 1).

Irrigation at $80 \%$ field capacity showed greater contents of soil moisture than those found at $40 \%$ irrigation for all types of soil conditioners under study (TABLE 1). However, the use of coffee husk showed higher estimates of soil moisture for both irrigation levels than those found for other types of soil conditioners under study. Treatments consisting of agricultural gypsum and the negative control showed lesser content of soil moisture at $80 \%$ irrigation, with no differences from each other. The content of soil moisture obtained for treatments consisting of organic compost and water-retaining polymer did not show any difference. However, treatments consisting of water-retaining polymer, agricultural gypsum and the negative control showed lesser content of soil moisture under water restrictions. 
TABLE 1 - Plant height, stem diameter, number of leaves, plagiotropic branches, dry weight of the aerial part, dry weight of the root, palisade parenchyma, spongy parenchyma, mesophile, xylem vessel diameter, number of xylem vessels, leaf water potential and soil moisture of coffee plants of coffee plants cultivated under different levels of irrigation and soil conditioners.

\begin{tabular}{|c|c|c|c|c|c|c|}
\hline \multirow{2}{*}{ Treatments } & \multicolumn{2}{|c|}{ Plant height } & \multicolumn{2}{|c|}{ Stem diameter } & \multicolumn{2}{|c|}{ Number of leaves } \\
\hline & $80 \%{ }^{\mathrm{a}}$ & $40 \%^{\mathrm{b}}$ & $80 \%$ & $40 \%$ & $80 \%$ & $40 \%$ \\
\hline Coffee husk & $49.8 \mathrm{Aa}$ & $55.3 \mathrm{Aa}$ & $6.61 \mathrm{Aa}$ & $6.60 \mathrm{Aa}$ & $46.6 \mathrm{Aa}$ & $44.3 \mathrm{Aa}$ \\
\hline Organic compost & $44.4 \mathrm{Ab}$ & $47.6 \mathrm{Ab}$ & $6.17 \mathrm{Aa}$ & $5.96 \mathrm{Aa}$ & $32.5 \mathrm{Ab}$ & $34.9 \mathrm{Ab}$ \\
\hline Water-retaining polymer & $42.5 \mathrm{Ab}$ & $35.6 \mathrm{Bc}$ & $5.72 \mathrm{Aa}$ & $5.28 \mathrm{Ab}$ & $36.4 \mathrm{Ab}$ & $13.9 \mathrm{Bc}$ \\
\hline Agricultural gypsum & $53.5 \mathrm{Aa}$ & $33.8 \mathrm{Bc}$ & $6.49 \mathrm{Aa}$ & $4.16 \mathrm{Bc}$ & $40.6 \mathrm{Aa}$ & $7.3 \mathrm{Bc}$ \\
\hline \multirow[t]{3}{*}{ Witness } & $51.4 \mathrm{Aa}$ & $36.3 \mathrm{Bc}$ & $6.31 \mathrm{Aa}$ & $4.39 \mathrm{Bc}$ & $35.3 \mathrm{Ab}$ & $9.0 \mathrm{Bc}$ \\
\hline & \multicolumn{2}{|c|}{$\begin{array}{c}\text { Plagiotropic } \\
\text { branches }\end{array}$} & \multicolumn{2}{|c|}{$\begin{array}{l}\text { Dry weight of } \\
\text { the aerial part }\end{array}$} & \multicolumn{2}{|c|}{$\begin{array}{c}\text { Dry weight of } \\
\text { the root }\end{array}$} \\
\hline & $80 \%$ & $40 \%$ & $80 \%$ & $40 \%$ & $80 \%$ & $40 \%$ \\
\hline Coffee husk & 7.1 Aa & $6.8 \mathrm{Aa}$ & 17.1 Aa & $16.9 \mathrm{Aa}$ & $3.3 \mathrm{Aa}$ & $3.8 \mathrm{Aa}$ \\
\hline Organic compost & $5.9 \mathrm{Aa}$ & $5.8 \mathrm{Aa}$ & $12.3 \mathrm{Aa}$ & $11.9 \mathrm{Ab}$ & $2.3 \mathrm{Ab}$ & $2.7 \mathrm{Ab}$ \\
\hline Water-retaining polymer & $6.0 \mathrm{Aa}$ & $2.6 \mathrm{Bb}$ & $7.5 \mathrm{Ac}$ & $3.3 \mathrm{Bc}$ & $1.8 \mathrm{Ab}$ & $1.2 \mathrm{Ac}$ \\
\hline Agricultural gypsum & $6.3 \mathrm{Aa}$ & $2.3 \mathrm{Bb}$ & $16.6 \mathrm{Ab}$ & $3.1 \mathrm{Bc}$ & $3.4 \mathrm{Aa}$ & $1.2 \mathrm{Bc}$ \\
\hline \multirow[t]{3}{*}{ Witness } & $6.1 \mathrm{Aa}$ & $1.8 \mathrm{Bb}$ & $12.7 \mathrm{Ab}$ & $3.1 \mathrm{Bc}$ & $2.9 \mathrm{Aa}$ & $1.2 \mathrm{Bc}$ \\
\hline & \multicolumn{2}{|c|}{$\begin{array}{c}\text { Palisade } \\
\text { parenchyma }\end{array}$} & \multicolumn{2}{|c|}{$\begin{array}{c}\text { Spongy } \\
\text { parenchyma }\end{array}$} & \multicolumn{2}{|c|}{ Mesophile } \\
\hline & $80 \% \%^{a}$ & $40 \%^{\mathrm{b}}$ & $80 \%$ & $40 \%$ & $80 \%$ & $40 \%$ \\
\hline Coffee husk & $47.8 \mathrm{Aa}$ & $45.1 \mathrm{Ab}$ & $180.6 \mathrm{Aa}$ & $180.5 \mathrm{Aa}$ & $226.0 \mathrm{Aa}$ & $222.7 \mathrm{Aa}$ \\
\hline Organic compost & $47.0 \mathrm{Aa}$ & $43.6 \mathrm{Ab}$ & $178.0 \mathrm{Aa}$ & $170.9 \mathrm{Aa}$ & $221.2 \mathrm{Aa}$ & $213.2 \mathrm{Aa}$ \\
\hline Water-retaining polymer & $47.7 \mathrm{Aa}$ & $47.8 \mathrm{Aa}$ & $168.5 \mathrm{Ba}$ & 189.1 Aa & $214.0 \mathrm{Ba}$ & $234.1 \mathrm{Aa}$ \\
\hline Agricultural gypsum & $45.9 \mathrm{Aa}$ & $42.6 \mathrm{Ab}$ & 177.2 Aa & $146.1 \mathrm{Bb}$ & $221.0 \mathrm{Aa}$ & $187.3 \mathrm{Bb}$ \\
\hline \multirow[t]{3}{*}{ Witness } & $43.3 \mathrm{Ba}$ & $49.3 \mathrm{Aa}$ & $172.8 \mathrm{Aa}$ & $174.1 \mathrm{Aa}$ & $214.0 \mathrm{Aa}$ & $226.2 \mathrm{Aa}$ \\
\hline & \multicolumn{2}{|c|}{$\begin{array}{l}\text { Xylem vessel } \\
\text { diameter }\end{array}$} & \multicolumn{2}{|c|}{$\begin{array}{c}\text { Number of xylem } \\
\text { vessels }\end{array}$} & \multicolumn{2}{|c|}{$\begin{array}{c}\text { Leaf water } \\
\text { potential }\end{array}$} \\
\hline & $80^{\circ}$ & $40 \%$ & $80 \%$ & $40 \%$ & $80 \%$ & $40 \%$ \\
\hline Coffee husk & $14.4 \mathrm{Aa}$ & $14.6 \mathrm{Aa}$ & $129.8 \mathrm{Aa}$ & $136.4 \mathrm{Aa}$ & $-0.99 \mathrm{Aa}$ & $-1.06 \mathrm{Aa}$ \\
\hline Organic compost & $14.4 \mathrm{Aa}$ & 13.1 Aa & 127.1 Aa & $129.3 \mathrm{Aa}$ & $-1.21 \mathrm{Aa}$ & $-1.51 \mathrm{Ab}$ \\
\hline Water-retaining polymer & $14.2 \mathrm{Aa}$ & $10.9 \mathrm{Bb}$ & 131.4 Aa & $116.7 \mathrm{Ab}$ & $-1.04 \mathrm{Aa}$ & $-2.56 \mathrm{Bc}$ \\
\hline Agricultural gypsum & $14.8 \mathrm{Aa}$ & $12.4 \mathrm{Bb}$ & 136.7 Aa & $94.17 \mathrm{Bc}$ & $-1.18 \mathrm{Aa}$ & $-2.84 \mathrm{Bc}$ \\
\hline \multirow[t]{3}{*}{ Witness } & $14.9 \mathrm{Aa}$ & $12.2 \mathrm{Bb}$ & $136.9 \mathrm{Aa}$ & $108.4 \mathrm{Bb}$ & $-1.22 \mathrm{Aa}$ & $-3.73 \mathrm{Bd}$ \\
\hline & \multicolumn{6}{|c|}{ Soil moisture } \\
\hline & \multicolumn{3}{|c|}{$80 \%$} & \multicolumn{3}{|c|}{$40 \%$} \\
\hline Coffee husk & \multicolumn{3}{|c|}{$38.08 \mathrm{Aa}$} & \multicolumn{3}{|c|}{$34.18 \mathrm{Ba}$} \\
\hline Organic compost & \multicolumn{3}{|c|}{$34.62 \mathrm{Ab}$} & \multicolumn{3}{|c|}{$25.52 \mathrm{Bb}$} \\
\hline Water-retaining polymer & \multicolumn{3}{|c|}{$34.02 \mathrm{Ab}$} & \multicolumn{3}{|c|}{$18.21 \mathrm{Bc}$} \\
\hline Agricultural gypsum & \multicolumn{3}{|c|}{$29.42 \mathrm{Ac}$} & \multicolumn{3}{|c|}{$16.74 \mathrm{Bc}$} \\
\hline Witness & & $27.19 \mathrm{Ac}$ & & & $15.89 \mathrm{Bc}$ & \\
\hline
\end{tabular}

${ }^{\mathrm{a}} 80 \%=$ levels of irrigation $80 \%$ of field capacity; ${ }^{\mathrm{b}} 40 \%=$ levels of irrigation $40 \%$ of field capacity.

Means followed by the same letter, uppercase in the line and lowercase in the column belong to the same cluster by the Scott-Knott test $(p<0.05)$. 
The organic compost showed anintermediate estimate of soil moisture when compared to other types of soil conditioners (TABLE 1).

The controlled release fertilizer associated with coffee husk promoted a significant increase in plant height, stem diameter and dry weight of the root system when compared to the conventional fertilizer (TABLE 2). Higher estimates of number of leaves and dry weight of the aerial part were found in controlled release fertilizer used for plants grown under coffee husk and organic compost. In addition, the use of controlled release fertilizer showed higher estimates of number of leaves for plants of the negative control. Regarding stem diameter, higher mean estimate was found for plants grown in conventional fertilizer associated with water-retaining polymer conditioner (TABLE 2).
Plants grown in conventional fertilizer, for different types of soil conditioners, did not differ from each other regarding plant height and stem diameter $(p>0.05)$ (TABLE 2). Plants grown in coffee husk showed higher estimates for both types of fertilizer, regarding number of leaves, dry weight of the aerial part and dry weight of the root system. Plants grown in controlled release fertilizer, under water-retaining polymer and with agricultural gypsum, as well as the negative control showed lesser estimates of stem diameter, number of leaves, dry weight of the aerial part and dry weight of the root system. In addition, lesser estimates were also found with regard to dry weight of the aerial part and dry weight of the root system for coffee plants under water-retaining polymer, when compared to other types of soil conditioners used in the study (TABLE 2).

TABLE 2 - Plant height, stem diameter, number of leaves, dry weight of the aerial part, dry weight of the root, stomatal density, adaxial epidermis thickness and leaf water potential of coffee plants cultivated using different fertilizers and soil conditioners.

\begin{tabular}{|c|c|c|c|c|c|c|}
\hline \multirow{2}{*}{ Treatments } & \multicolumn{2}{|c|}{ Plant height } & \multicolumn{2}{|c|}{ Stem diameter } & \multicolumn{2}{|c|}{ Number of leaves } \\
\hline & $\mathrm{CRF}^{\mathrm{a}}$ & $\mathrm{CF}^{\mathrm{b}}$ & $\mathrm{CRF}$ & $\mathrm{CF}$ & $\mathrm{CRF}$ & $\mathrm{CF}$ \\
\hline Coffee husk & $57.56 \mathrm{Aa}$ & $47.56 \mathrm{Ba}$ & $7.18 \mathrm{Aa}$ & $6.04 \mathrm{Ba}$ & $50.25 \mathrm{Aa}$ & $40.67 \mathrm{Ba}$ \\
\hline Organic compost & $48.88 \mathrm{Ab}$ & $43.06 \mathrm{Aa}$ & $6.52 \mathrm{Aa}$ & $5.61 \mathrm{Aa}$ & $40.38 \mathrm{Ab}$ & $27.00 \mathrm{Bb}$ \\
\hline Water-retaining polymer & $37.06 \mathrm{Ac}$ & $41.06 \mathrm{Aa}$ & $4.97 \mathrm{Bb}$ & $6.02 \mathrm{Aa}$ & $22.25 \mathrm{Ac}$ & $28.00 \mathrm{Ab}$ \\
\hline Agricultural gypsum & $43.94 \mathrm{Ab}$ & $43.31 \mathrm{Aa}$ & $5.41 \mathrm{Ab}$ & $5.25 \mathrm{Aa}$ & $28.00 \mathrm{Ac}$ & $21.75 \mathrm{Ac}$ \\
\hline \multirow[t]{3}{*}{ Witness } & $45.75 \mathrm{Ab}$ & $41.88 \mathrm{Aa}$ & $5.51 \mathrm{Ab}$ & $5.19 \mathrm{Aa}$ & $26.88 \mathrm{Ac}$ & $17.38 \mathrm{Bc}$ \\
\hline & \multicolumn{2}{|c|}{$\begin{array}{l}\text { Dry weight of } \\
\text { the aerial part }\end{array}$} & \multicolumn{2}{|c|}{$\begin{array}{l}\text { Dry weigth of } \\
\text { the root }\end{array}$} & \multicolumn{2}{|c|}{ Stomatal density } \\
\hline & $\mathrm{CRF}$ & $\mathrm{CF}$ & CRF & $\mathrm{CF}$ & $\mathrm{CRF}$ & $\mathrm{CF}$ \\
\hline Coffee husk & $21.16 \mathrm{Aa}$ & $12.96 \mathrm{Ba}$ & $4.06 \mathrm{Aa}$ & $3.04 \mathrm{Ba}$ & $1617 \mathrm{Ab}$ & $1606 \mathrm{Ab}$ \\
\hline Organic compost & $14.88 \mathrm{Ab}$ & $9.31 \mathrm{Bb}$ & $2.95 \mathrm{Ab}$ & $2.04 \mathrm{Ab}$ & $1436 \mathrm{Ab}$ & $1602 \mathrm{Ab}$ \\
\hline Water-retaining polymer & $4.62 \mathrm{Ad}$ & $6.18 \mathrm{Ab}$ & 1.13 Ad & $1.83 \mathrm{Ab}$ & $1785 \mathrm{Aa}$ & $1873 \mathrm{Ab}$ \\
\hline Agricultural gypsum & $10.28 \mathrm{Ac}$ & $9.40 \mathrm{Ab}$ & $2.39 \mathrm{Ac}$ & $2.23 \mathrm{Ab}$ & $1894 \mathrm{Aa}$ & $1658 \mathrm{Ab}$ \\
\hline \multirow[t]{3}{*}{ Witness } & $8.86 \mathrm{Ac}$ & $6.94 \mathrm{Ab}$ & $2.43 \mathrm{Ac}$ & $1.79 \mathrm{Ab}$ & $1973 \mathrm{Ba}$ & $2441 \mathrm{Aa}$ \\
\hline & \multicolumn{3}{|c|}{ Thickness adaxial epidermis } & \multicolumn{3}{|c|}{ Leaf water potential } \\
\hline & CRF & \multicolumn{2}{|c|}{$\mathrm{CF}$} & \multicolumn{2}{|c|}{ CRF } & $\mathrm{CF}$ \\
\hline Coffee husk & $24.46 \mathrm{Aa}$ & \multicolumn{2}{|c|}{$24.34 \mathrm{Aa}$} & \multicolumn{2}{|c|}{$-1.09 \mathrm{Aa}$} & $-0.95 \mathrm{Aa}$ \\
\hline Organic compost & $22.90 \mathrm{Ba}$ & \multicolumn{2}{|c|}{$24.95 \mathrm{Aa}$} & \multicolumn{2}{|c|}{$-1.38 \mathrm{Aa}$} & $-1.35 \mathrm{Ab}$ \\
\hline Water-retaining polymer & $23.59 \mathrm{Ba}$ & \multicolumn{2}{|c|}{$25.29 \mathrm{Aa}$} & \multicolumn{2}{|c|}{$-1.91 \mathrm{Ab}$} & -1.69 Ac \\
\hline Agricultural gypsum & $23.00 \mathrm{Aa}$ & \multicolumn{2}{|c|}{$22.12 \mathrm{Ab}$} & \multicolumn{2}{|c|}{$-1.94 \mathrm{Ab}$} & $-2.07 \mathrm{Ad}$ \\
\hline Witness & $22.39 \mathrm{Aa}$ & \multicolumn{2}{|c|}{$22.37 \mathrm{Ab}$} & \multicolumn{2}{|c|}{$-2.25 \mathrm{Ab}$} & $-2.70 \mathrm{Be}$ \\
\hline
\end{tabular}

${ }^{\mathrm{a}} \mathrm{CRF}=$ controlled release fertilizer; ${ }^{\mathrm{b}} \mathrm{CF}=$ conventional fertilizer.

Means followed by the same letter, uppercase in the line and lowercase in the column belong to the same cluster by the Scott-Knott test $(p<0.05)$. 
Beyond these findings, the stomatal density was greater in plants of the negative control, as well as those grown in conventional fertilizer. Treatments consisting of controlled release fertilizer showed lesser estimates of stomatal density in coffee plants grown in a soil without conditioners, when compared to treatment containing conventional fertilizer. Lesser estimates of stomatal density were also found for treatments containing controlled release fertilizer associated with coffee husk and organic compost (TABLE 2).

Plants of the negative control and with agricultural gypsum, both with conventional fertilizer added as type of fertilizer, showed lesser adaxial epidermis thickness (TABLE 2). A similar trend was found for the same treatments regarding leaf water potential, in which lesser estimates were obtained (TABLE 2).

Plants grown in soils without conditioners showed greater estimates of leaf water potential for treatments containing controlled release fertilizer than for treatments containing conventional fertilizer. However, regarding conventional fertilizer, different estimates of leaf water potential were found in plants grown in different types of soil conditioners, as follows: greater estimates for coffee husk, followed by organic compost, waterretaining polymer, agricultural gypsum and the control treatment. Coffee plants grown in coffee husk and organic compost, with controlled release fertilizer added, showed greater estimates of leaf water potential when compared to other types of soil conditioners (TABLE 2).

The controlled release fertilizer provided greater estimates of palisade parenchyma thickness and water use efficiency when compared to treatments with conventional fertilizer added, at $40 \%$ irrigation (TABLE 3 ). Regarding number of xylem vessels, there was no statistical difference between types of fertilizers for plants grown under the same conditions (TABLE 3).

Regarding palisade parenchyma thickness and number of xylem vessels, there was no difference between levels of irrigation in treatments with controlled release fertilizer added. The use of conventional fertilizer caused decreasing of estimates of palisade parenchyma thickness and number of xylem vessels at $40 \%$ irrigation. The highest water use efficiency at the same level of irrigation was found in coffee plants of treatments containing controlled release fertilizer (TABLE $3)$.

The irrigation at $80 \%$ of field capacity allowed the obtaining of greater estimates of total root length, adaxial epidermis thickness, photosynthetic rate, stomatal conductance and transpiration rate. Treatments with water restriction at $40 \%$ field capacity showed greater estimates of stomatal density and phloem region (TABLE 4).

The controlled release fertilizers provided greater estimates of number of plagiotropic branches and photosynthetic rate, regardless of the level of irrigation and type of soil conditioner used (TABLE 5).

The coffee husk provided greater estimates of total root length, photosynthetic rate, stomatal conductance and transpiration rate when compared to other types of soil conditioners under study (the control treatment). Besides, treatments under water-retaining polymer showed lesser estimates of total root length (TABLE 6).

Treatments containing coffee husk, organic compost and water-retaining polymer showed greater estimates of the ratio polar diameter/ equatorial diameter of the stomata when compared to treatments containing agricultural gypsum and the treatment without soil conditioners (TABLE 6).

The water deficit is found to be one of the most limiting of climatological factors in coffee growing, with direct effect in the decrease of coffee production (APARECIDO; ROLIM; SOUZA, 2015). In this work, the lesser water availability (40\% field capacity) led to low plants growth and lesser amount of plants biomass (aerial part and root system), decrease in gas exchange and changes in the leaf tissues when compared to plants irrigated at $80 \%$ of field capacity.

Assis et al. (2014) demonstrate the importance of water on coffee growing and variations recorded on vegetative development in plants grown under water restrictions. In this study, plants irrigated at $80 \%$ field capacity and/or cultivated in soils containing conditioners such as coffee husk, agricultural gypsum, water-retaining polymer and organic compost showed greater vegetative growth when compared to plants cultivated under water restrictions.

The efficiency of plants in water and nutrients uptake varies significantly according to water restrictions adopted in the production system. Thus, plants grown at $40 \%$ field capacity showed lesser growth of the root system. Similar results were reported in Souza et al. (2016), where coffee plants grown at $25 \%$ irrigation level showed lesser ratio between dry weight of the root system and dry weight of shoots. These authors also found that $100 \%$ irrigation causes damages to plants root system due to the decrease of soil aeration. 
TABLE 3 - Palisade parenchyma thickness, number of xylem vessels and water use efficiency of coffee plants submitted to different levels of irrigation and fertilizers.

\begin{tabular}{ccccccc}
\hline & \multicolumn{2}{c}{ Palisade parenchyma } & \multicolumn{2}{c}{ Number of xylem vessels } & \multicolumn{2}{c}{ Water use efficiency } \\
\hline Irrigation & $\mathrm{CRF}^{\mathrm{a}}$ & $\mathrm{CF}^{\mathrm{b}}$ & $\mathrm{CRF}$ & $\mathrm{CF}$ & $\mathrm{CRF}$ & $\mathrm{CF}$ \\
\hline $80 \%$ of field capacity & $45.4 \mathrm{Aa}$ & $47.26 \mathrm{Aa}$ & $119.0 \mathrm{Ba}$ & $145.8 \mathrm{Aa}$ & $4.20 \mathrm{Ab}$ & $4.51 \mathrm{Aa}$ \\
$40 \%$ of field capacity & $47.6 \mathrm{Aa}$ & $43.76 \mathrm{Bb}$ & $113.0 \mathrm{Aa}$ & $121.0 \mathrm{Ab}$ & $5.22 \mathrm{Aa}$ & $4.40 \mathrm{Ba}$ \\
\hline
\end{tabular}

${ }^{\mathrm{a}} \mathrm{CRF}=$ controlled release fertilizer; ${ }^{\mathrm{b}} \mathrm{CF}=$ conventional fertilizer.

Means followed by the same letter, uppercase in the line and lowercase in the column belong to the same cluster by the Scott-Knott test $(p<0.05)$.

TABLE 4 - Means of the total root length, stomatal density, adaxial epidermis thickness, phloem thickness, photosynthetic rate, stomatal conductance and transpiration rate of coffee plants submitted to different levels of irrigation.

\begin{tabular}{cccccccc}
\hline Irrigation & $\begin{array}{c}\text { Total root } \\
\text { length }\end{array}$ & $\begin{array}{c}\text { Stomatal } \\
\text { density }\end{array}$ & $\begin{array}{c}\text { Adaxial } \\
\text { epidermis }\end{array}$ & Phloem & $\begin{array}{c}\text { Photosynthetic } \\
\text { rate }\end{array}$ & $\begin{array}{c}\text { Stomatal } \\
\text { conductance }\end{array}$ & $\begin{array}{c}\text { Transpiration } \\
\text { rate }\end{array}$ \\
\hline $\begin{array}{c}80 \% \text { of } \\
\text { field capacity }\end{array}$ & $593.9 \mathrm{a}$ & $1607 \mathrm{~b}$ & $24.60 \mathrm{a}$ & $47.16 \mathrm{~b}$ & $6.28 \mathrm{a}$ & $0.07 \mathrm{a}$ & $1.40 \mathrm{a}$ \\
$\begin{array}{c}40 \% \text { of } \\
\text { field capacity }\end{array}$ & $384.8 \mathrm{~b}$ & $1970 \mathrm{a}$ & $22.49 \mathrm{~b}$ & $50.32 \mathrm{a}$ & $3.73 \mathrm{~b}$ & $0.04 \mathrm{~b}$ & $0.77 \mathrm{~b}$ \\
\hline
\end{tabular}

Means followed by the same letter in the column belong to the same cluster by the Scott-Knott test $(p<0.05)$.

TABLE 5 - Mean of the number of plagiotropic branches and photosynthetic rate of coffee plants cultivated using different fertilizers.

\begin{tabular}{lcc}
\hline Fertilizer & $\begin{array}{c}\text { Number of } \\
\text { plagiotropic branches }\end{array}$ & $\begin{array}{c}\text { Photosynthetic } \\
\text { rate }\end{array}$ \\
\hline Controlled release & $5.4 \mathrm{a}$ & $5.43 \mathrm{a}$ \\
Conventional & $4.7 \mathrm{~b}$ & $4.58 \mathrm{~b}$ \\
\hline
\end{tabular}

Means followed by the same letter in the column belong to the same cluster by the Scott-Knott test $(p<0.05)$.

TABLE 6 - Means of the total root length, polar diameter/equatorial diameter relation of the stomata, photosynthetic rate, stomatal conductance and transpiration rate of coffee plants with different soil conditioners.

\begin{tabular}{lccccc}
\hline Conditioner & $\begin{array}{c}\text { Root } \\
\text { length }\end{array}$ & $\begin{array}{c}\text { Polar / } \\
\text { equatorial } \\
\text { diameter relation } \\
\text { of the stomata }\end{array}$ & Photosynthetic rate & $\begin{array}{c}\text { Stomatal } \\
\text { conductance }\end{array}$ & Transpiration rate \\
\hline Coffee husk & $904.8 \mathrm{a}$ & $1.88 \mathrm{a}$ & $7.52 \mathrm{a}$ & $0.09 \mathrm{a}$ & $1.64 \mathrm{a}$ \\
Organic compost & $562.4 \mathrm{~b}$ & $1.90 \mathrm{a}$ & $4.69 \mathrm{~b}$ & $0.05 \mathrm{~b}$ & $1.13 \mathrm{~b}$ \\
Water-retaining polymer & $262.4 \mathrm{c}$ & $1.83 \mathrm{a}$ & $4.06 \mathrm{~b}$ & $0.04 \mathrm{~b}$ & $0.83 \mathrm{c}$ \\
Agricultural gypsum & $436.0 \mathrm{~b}$ & $1.73 \mathrm{~b}$ & $4.09 \mathrm{~b}$ & $0.04 \mathrm{~b}$ & $0.76 \mathrm{c}$ \\
Witness & $281.1 \mathrm{c}$ & $1.77 \mathrm{~b}$ & $4.54 \mathrm{~b}$ & $0.05 \mathrm{~b}$ & $1.05 \mathrm{~b}$ \\
\hline
\end{tabular}

Means followed by the same letter in the column belong to the same cluster by the Scott-Knott test $(p<0.05)$. 
Coffee plants show anatomical and physiological changes related to the existing limiting growing factors such as water stress and radiation exposure levels (MENEZES-SILVA et al., 2017). In this study, difference in the leaf water potential, tissue spacing, and vascular bundles were found in plants grown under water restrictions.

Changes in the diameter and number of xylem vessels indicate the adaptation level of plants grown under adverse environmental conditions (CASTANHEIRA et al., 2016; HACKE; SPICER; SCHREIBER, 2017). Smaller diameter and higher number of xylem vessels indicate high plants efficiency for sap conduction since they decrease chances for air embolism in plants grown, for example, under water stress (SEVANTO et al., 2018). However, the decrease in number of xylem vessels found in treatments containing agricultural gypsum and the control treatment in this study may be the result of damages caused by water restriction to plants grown at $40 \%$ irrigation. In addition, these treatments showed values of leaf water potential estimated in $-2.84 \mathrm{Mpa}$ for treatments containing agricultural gypsum and $-3.73 \mathrm{MPa}$ for the control treatment, which indicate an existing sharp water deficit in the production system. Thus, the reduction in xylem vessel diameter reflects the effect of water restrictions in plants grown in different types of soil conditioners, when compared to plants grown at $80 \%$ field capacity.

The higher spacing of the phloem observed in plants grown under water stress is also an indicating of plants adaptation form developed to address adverse growing conditions, to allow greater translocation of photoassimilates and favor plants growth (SEVANTO et al., 2018).

Higher estimates of palisade parenchyma thickness found in treatments with no soil conditioners indicate the existing anatomical adaptations of plants to develop under water deficit conditions. The palisade parenchyma is part of the leaf mesophyll and can have direct effect on plants gas exchanges. However, plants with greater tissue thickness tend to tolerate water deficiency even without a higher photosynthetic capacity (BINKS et al., 2016).

Water availability can alter stomatal density and the relationship between these variables may be described by means of an inverse proportionality. In addition, the decreased in size of epidermis cells results in greater number of stomata per area
(SILVA et al., 2014). These findings explain the trends obtained for some variables, for example, higher estimates of stomatal density and lesser estimates of adaxial epidermis thickness obtained in plants grown under different levels of water availability.

Anatomical changes found in this work do not indicate levels of tolerance of water stress since aspects related to plants physiology must also be taken into consideration. Thus, although there were anatomical changes, lesser estimates of gas exchanges in coffee plants grown under water restriction were found in this study, which reveals low plant growth.

Lesser estimates of leaf water potential $(-3.73 \mathrm{Mpa})$ found in coffee plants grown with no soil conditioner and the low irrigation level, indicate an extreme water stress condition. Studies describe estimates of leaf water potential about $-2.15 \mathrm{Mpa}$ found in coffee plants, which is usually found in plants at the permanent wilting point (SANTOS; MAZZAFERA, 2012). In this work, plants grown at $40 \%$ field capacity showed lesser estimates of leaf water potential, which probably reflects lesser estimates of the following variables: plant height, number of leaves, number of plagiotropic branches, dry weight of the aerial part, xylem vessel diameter, total root length, photosynthetic rate, stomatal conductance and transpiration rate.

The low soil moisture has a direct effect in the decrease of leaf water potential in coffee plants irrigated at $40 \%$. Beyond this effect, lesser contents of soil moisture were found in treatments irrigated at $40 \%$ field capacity, which may have affected the pattern of morphophysiological parameters under study. Studies state that the water availability affects significantly the plants growth and development, since the water participates in the transport and translocation of photoassimilates, cellular expansion and opening and closing of stomata (MCELRONE et al., 2013).

The controlled release fertilizer was found to be an efficient type of fertilizer used to stimulate the coffee plants growth since it led to greater estimates of plant height, number of leaves, dry weight of the aerial part and dry weight of the root system than those found in conventional fertilizer. This soil effect occurred due to the significant supplementation of $\mathrm{N}$ and $\mathrm{K}$ existing in the controlled release fertilizer, as well as the lesser level of nutrient losses through volatilization and leaching. The controlled release fertilizer is usually 
formulated seeking for optimization of plants nutrition, which depends on the following factors: coating thickness, plants nutrients requirements and level of potential losses that occur in the production process (TIMILSENA et al., 2015).

The controlled release fertilizer favors indirectly the level of water stress, since higher estimates of leaf water potential were found in plants of treatments containing controlled release fertilizer and the treatment with no soil conditioners. In the same context, the increase in estimates of stomatal density becomes expressive in plants impacted by water restrictions (SILVA et al., 2014). Besides, the increase in stomatal density is usually recorded in plants grown under increased water restriction. This is associated to the size of stomata, where smaller sized stomata can quickly open and close, then increasing stomatal conductance (XU; ZHOU, 2008).

In this study, it highlights the estimate of controlled release fertilizer found for coffee plants grown under water restrictions, which was higher and probably reduced the transpiration rate without affecting the photosynthetic rate of plants (FARES et al., 2016). Higher estimates of palisade parenchyma thickness can be associated to higher estimates of water use efficiency, since the palisade parenchyma is a chlorophyllcontaining tissue specialized for photosynthesis (TERASHIMA et al., 2011). Thus, the thickness of this plant tissue may have contributed to the maintaining the photosynthetic efficiency in coffee plants grown in soils with controlled release fertilizer added. A higher photosynthetic rate was recorded in coffee plants for treatments with controlled release fertilizer added, regardless of the level of irrigation and type of soil conditioners. This finding had effect on estimates of number of plagiotropic branches due to higher production and translocation of photoassimilates to promote plants growth.

Coffee plants grown in soils with controlled release fertilizer added, associated with coffee husk, showed a greater vegetative growth than those found in coffee plants grown only in soils with conventional fertilizer added, indicating a beneficial interaction between these plants growth factors. This effect may be related to substantial supplementation of nutrients existing in both this type of fertilizer and the coffee husk, which is also a source of $\mathrm{N}$ and K (FERNANDES et al., 2013).

The importance of studying types of soil conditioners is highlighted, since the coffee husk and organic compost provided higher growth rate and greater number of vascular bundles, with greater estimates of xylem vessel diameter in plants grown under water restriction conditions. This factors determining relationship has possibly occurred in function of types of soil covers provided by soil conditioners under study, which contributed to the decreased of water losses through evapotranspiration and the obtaining of higher contents of soil moisture. The coffee husk and organic compost are sources of organic matter, which allow greater water retention and improve soil properties. Fernandes et al. (2013) found greater productivity in coffee plants of treatments containing coffee husk, due to the improvement of the physical-chemical and biological soil properties, as well as gradual availability of nutrients provided by soil organic matter fractions found in soils containing coffee husk.

Despite the water-retaining polymer providing low plants growth as found in plants grown in soils containing coffee husk and organic compost, this soil conditioner allowed obtaining estimates of stem diameter, dry weight of the root system and number of xylem vessels with similar trend for either plants grown under water restriction or not. Regarding these variables, plants grown in soils containing water-retaining polymer were subjected to water stress conditioning treatments. Beyond these findings, coffee plants grown under water-retaining polymer showed greater estimates of plant height, dry weight of the aerial part, total dry weight and absolute growth when compared to plants of treatments grown without soil polymers (SOUZA et al., 2016).

Regarding the water-retaining polymer, estimates of spongy parenchyma thickness and mesophile thickness at $40 \%$ irrigation level were greater those found in plants grown at $80 \%$ irrigation level. The higher thickness of spongy parenchyma and leaf mesophyll in plants grown under water restrictions can favor the gas exchanges due to high accumulation and storage of $\mathrm{CO}_{2}$ required for photosynthesis (TERASHIMA et al., 2011).

Among types of soil conditioners under study, it highlights the effect of agricultural gypsum on the following anatomical variables: palisade parenchyma thickness, spongy parenchyma thickness, mesophile thickness and number of xylem vessels, which was found to be lesser that estimates found in other treatments and the treatment with no soil conditioners. 
Coffee plants grown in soils without conditioners at $40 \%$ irrigation level, showed lesser estimates of leaf water potential, i.e., this treatment causes greater water stress. This finding showed that soil conditioners are prominent determining factors in the management of water deficit in coffee growing.

Results obtained in this study show that the coffee husk was able to provide greater gas exchanges and total root length to coffee plants, regardless of the level of irrigation. This is one of soil conditioners that allowed obtaining higher estimate of the ratio polar diameter/equatorial diameter of the stomata. High estimates of soil moisture in plants grown in this type of soil conditioner indicates high photosynthetic performance, regardless of the level of irrigation, resulting in significant production and translocation of photoassimilates and greater estimates of total root length. Studies indicate that high estimates of the ratio polar diameter/equatorial diameter of the stomata favor photosynthetic capacity in coffee plants grown in soils with coffee husk. Besides, the increase in the polar diameter of stomata can favor the absorption of $\mathrm{CO}_{2}$ required for photosynthesis, resulting in high production of energy and plant growth (SOUZA et al., 2010).

\section{CONCLUSIONS}

Controlled release fertilizers and soil conditioners were found to be potential agronomic techniques for the implementation of a water restriction attenuation plan in coffee plantations.

The coffee husk allowed greater plant growth under water restriction, thus, being the most appropriate type of soil conditioner recommended for mitigating the effects of water deficit.

\section{ACKNOWLEDGMENTS}

The authors acknowledge FAPEMIG for providing the scholarships.

\section{REFERENCES}

APARECIDO, L.E.O.; ROLIM, G.S.; SOUZA, P.S. Sensitivity of newly transplanted coffee plants to climatic conditions at altitudes of Minas Gerais, Brazil. Australian Journal of Crop Science, Queensland, v. 9, n. 2, p. 160-167, 2015.

ASSIS, G.A. et al. Correlation between coffee plant growth and yield as function of water supply regime and planting density. Bioscience Journal, Uberlandia, v. 30, n. 3, p. 666-676, 2014.
BINKS, O. et al. Limited acclimation in leaf anatomy to experimental drought in tropical rainforest trees. Tree physiology, Oxford, v. 36, n. 12, p. 1550-1561, 2016.

BUNN, C. et al. A bitter cup: climate change profile of global production of Arabica and Robusta coffee. Climatic Change, v.129, n. 1-2, p.89-101, 2015.

CASTANHEIRA, D.T. et al. 2016. Potential use of anatomical and physiological characteristics in the selection of coffee progenies. Coffee Science, Lavras, v. 11, n. 3, p. $375-386,2016$.

FARES, A. et al. Irrigation water requirements for seed corn and coffee under potential climate change scenarios. Journal of Water and Climate Change, v.7, n.1, p. 39-51, 2016.

FERNANDES, A.L.T. et al. Reduction of mineral fertilization of arabic coffee using coffee straw. Coffee Science, Lavras, v.8, n.3, p.324-336, 2013.

GUIMARÃES, P. T. G. et al. Cafeeiro. In: RIBEIRO, A. C.; GUIMARÃES, P. T. G.; ALVARES, V. H. (Ed). Recomendação para o uso de corretivos e fertilizantes em Minas Gerais: $\mathbf{5}^{\mathrm{a}}$ aproximação. Viçosa, MG: Editora da UFV, 1999. p. 289-302.

HACKE, U.G.; SPICER, R.; SCHREIBER, S.G. An ecophysiological and developmental perspective on variation in vessel diameter. Plant, cell \& environment, v.40, n.6, p. 831-845, 2017.

INTERGOVERNMENTAL PANEL ON CLIMATE CHANGE - IPCC. Climate Change 2014: Impacts, Adaptation and Vulnerability. Summary for Policymakers. WG II. Genebra: IPCC, 2014.

LANNA, A.C. et al. Physiological characterization of common bean ('Phaseolus vulgaris' L.) genotypes, water-stress induced with contrasting response towards drought. Australian Journal of Crop Science, Queensland, v.10, n.1, p.1-6, 2016.

MALAVOLTA, E. Manual de química agrícola: adubos e adubação. 3ed. São Paulo: Agronômica Ceres, 1981. 584p.

MCELRONE, A.J. et al. Water uptake and transport in vascular plants. Nature Education Knowledge, Cambridge, v.4, p.1-6, 2013.

MENEZES-SILVA, P.E. et al. Photosynthetic and metabolic acclimation to repeated drought events play key roles in drought tolerance in coffee. Journal of Experimental Botany, Oxford, v.68, p.4309-4322, 2017. 
O'BRIEN, T.P.; FEDER, N.; MCCULLY, M.E. Polychromatic staining of plant cell walls by toluidine blue O. Protoplasma. v. 59, n. 2, p. 368-373, 1964.

R DEVELOPMENT CORE TEAM. R: a language and environment for statistical computing. Vienna: R Foundation for Statistical Computing, 2016. Disponível em: <http://www.R-project.org $>$. Acesso em: 10 Agosto, 2018.

SANTOS, W.J.R. et al. Soil moisture in the root zone and its relation to plant vigor assessed by remote sensing at management scale. Geoderma, v. 221-222, n. 1, p. 91-95, 2014.

SANTOS, A.B.; MAZZAFERA, P. Dehydrins are highly expressed in water stressed plants of two coffee species. Tropical Plant Biology, New York, v. 5, n. 3, p. $218-232,2012$

SEVANTO, S. et al. Is desiccation tolerance and avoidance reflected in xylem and phloem anatomy of two coexisting aridzone coniferous trees?. Plant, Cell \& environment, v.41, p.1551-1564, 2018.

SILVA, H. et al. Relationships between leaf anatomy, morphology, and water use efficiency in Aloe vera (L) Burm f. as a function of water availability. Revista Chilena de Historia Natural, Santiago, v.87, p.1-10, 2014.

SOUZA, T.C. et al. Leaf plasticity in successive selection cycles of' Saracura maize in response to periodic soil flooding. Pesquisa Agropecuária Brasileira, Brasilia, v.45, n.1, p.16-24, 2010.
SOUZA, T.C. et al. Morphophysiology, morphoanatomy, and grain yield under field conditions for two maize hybrids with contrasting response to drought stress. Acta Physiologiae Plantarum, v.35, n.11, p.3201-3211, 2013.

SOUZA, A.J.J. et al. Quantitative analysis of growth in coffee plants cultivated with a water-retaining polymer in an irrigated system. Revista Ciência Agronômica, Fortaleza, v.47, n.1, p.162-171, 2016.

TAIZ, L.; ZEIGER, E. Fisiologia vegetal. 5ed. Porto Alegre: ArtMed, 2013. 918p.

TERASHIMA, I. et al. Leaf functional anatomy in relation to photosynthesis. Plant Physiology, v.155, n.1, p.108-116, 2011.

TIMILSENA, Y.P. et al. Enhanced efficiency fertilisers: a review of formulation and nutrient release patterns. Journal of the Science and Food Agriculture, v.95, n.6, p.1131-1142, 2015.

XU, Z.; ZHOU, G. Responses of leaf stomatal density to water status and its relationship with photosynthesis in a grass. Journal of experimental botany, Oxford, v.59, n.12, p.3317-3325, 2008.

YAN, J. et al. High photosynthetic rate and water use efficiency of Miscanthus lutarioriparius characterize an energy crop in the semiarid temperate region. Gcb Bioenergy, Illinois, v.7, n.2, p.207-218, 2015. 